\title{
Image-based analysis of quantitative morphological characteristics of wild potato tubers using the desktop application SeedCounter
}

\author{
K.A. Ivanova ${ }^{1}$, E.G. Komyshev ${ }^{1}$, M.A. Genaev ${ }^{1,2}$, A.A. Egorova ${ }^{1,2}$, K.A. Koloshina ${ }^{1}$, N.A. Chalaya ${ }^{3}$, \\ D.A. Afonnikov ${ }^{1,2}$, A.V. Kochetov ${ }^{1,2}$, E.V. Rogozina ${ }^{3}$, S.V. Gerasimova ${ }^{1,2} \otimes$

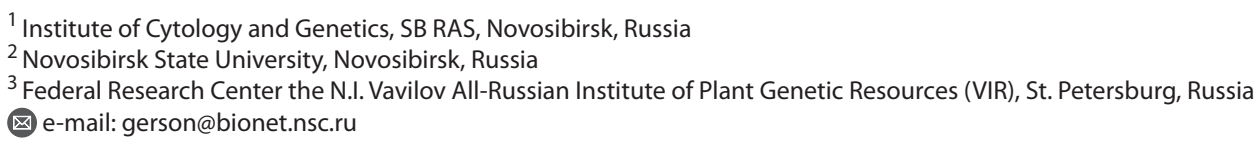

The development of quantitative digital phenotyping methods for evaluation of wild potato (section Petota Dumort., genus Solanum L.) tuberization is required for annotation of genebank collections and selection of the suitable donor material for potato breeding. There are no available methods specifically designed for the quantitative analysis of wild potato tuber morphology. The current study is devoted to evaluation of wild potato tubers' morphological characteristics using a digital image processing technique. For this purpose, the mobile application SeedSounter developed previously for grain analysis was specifically adapted for tuber phenotyping. The application estimates the number and shape of objects scattered on a standard sheet of white paper (i.e. A3 or A4). Twelve accessions from the VIR genebank collection belonging to nine Petota species were grown in pots protected with garden fabric during the growing season of cultivated potato (Novosibirsk region). Tubers were collected form plants of nine genotypes. Three genotypes did not produce tubers. The weight of tubers collected from each plant was measured. The tuber yield from each plant was analyzed using SeedCounter (http://wheatdb.org/seedcounter). The number of tubers per plant was counted; the following characteristics were extracted from the images of individual tubers: length, width, projected area, length to width ratio, circularity, roundness, rugosity and solidity. One-way ANOVA showed a significant effect of genotype on all measured characteristics. A pairwise comparison of nine Petota accessions using all measured parameters revealed statistically significant differences between $86 \%$ of pairs. The overall tuber yield volume for each plant was calculated as a sum of volumes of individual tubers; tuber volume was calculated from its length to width ratio and projected area. A strong correlation between the evaluated tuber yield volume and yield weight was shown. We propose tuber yield volume as a characteristic for a general evaluation of tuberization for wild potato, implementing the four-step scale from 0 to 3 . According to this characteristic, the twelve wild potato accessions studied could be divided into four groups with different tuberization abilities. The evaluated tuberization ability is partially in accordance with previously obtained VIR data. The results presented demonstrate the possibility to use SeedCounter for wild potato collections phenotyping.

Key words: Solanum; Petota; digital phenotyping of plants; wild potato species; SeedCounter; tuberization.

For citation: Ivanova K.A., Komyshev E.G., Genaev M.A., Egorova A.A., Koloshina K.A., Chalaya N.A., Afonnikov D.A., Kochetov A.V., Rogozina E.V., Gerasimova S.V. Image-based analysis of quantitative morphological characteristics of wild potato tubers using the desktop application SeedCounter. Vavilovskii Zhurnal Genetiki i Selektsii =Vavilov Journal of Genetics and Breeding. 2019;23(5):519-526. DOI 10.18699/VJ19.35-o

\section{Оценка количественных характеристик клубнеобразования дикого картофеля на основе анализа изображений клубней с использованием компьютерного приложения SeedCounter}

\footnotetext{
К.А. Иванова ${ }^{1}$, Е.Г. Комышев ${ }^{1}$, М.А. Генаев ${ }^{1,2}$, А.А. Егорова ${ }^{1,2}$, К.А. Колошина ${ }^{1}$, Н.А. Чалая ${ }^{3}$, А.А. Афонников ${ }^{1,2}$, А.В. Кочетов ${ }^{1,2}$, Е.В. Рогозина ${ }^{3}$, С.В. Герасимова ${ }^{1,2}$ 困

1 Федеральный исследовательский центр Институт цитологии и генетики Сибирского отделения Российской академии наук, Новосибирск, Россия

${ }^{2}$ Новосибирский национальный исследовательский государственный университет, Новосибирск, Россия

${ }^{3}$ Федеральный исследовательский центр Всероссийский институт генетических ресурсов растений им. Н.И. Вавилова (ВИР), Санкт-Петербург, Россия 凶e-mail: gerson@bionet.nsc.ru
}

Применение методов количественного цифрового фенотипирования для анализа параметров клубнеобразования диких клубненосных видов картофеля актуально для аннотации коллекций и для отбора оптимального донорного материала в работах по селекции культурного картофеля. На сегодняшний 


\begin{abstract}
день в литературе не описано методов, позволяющих объективно количественно оценить морфологические параметры клубней дикого картофеля. В настоящей работе был проведен эксперимент по оценке морфологических характеристик клубней диких видов секции Petota Dumort. рода Solanum L. при помощи мобильного приложения SeedCounter, анализирующего изображения объектов, размещенных на стандартном листе бумаги. Двенадцать образцов генотипов из коллекции ВИР, относящихся к девяти диким видам, были выращены в вегетационных сосудах, расположенных в парнике, обтянутом укрывным материалом, в сроки вегетации культурного картофеля (Новосибирская область). Урожай клубней получен с представителей девяти генотипов. Измерена масса клубней с одного растения, урожай каждого растения проанализирован при помощи настольной версии приложения SeedCounter (http://wheatdb.org/seedcounter). Произведен подсчет клубней, для каждого клубня получены следующие характеристики: длина, ширина, площадь проекции на лист бумаги, отношение длины к ширине, округлость, закругленность, шероховатость и компактность. При попарном сравнении девяти видов по перечисленным параметрам были выявлены достоверные различия в 86 \% исследуемых пар. На основании показателей отношения длины к ширине и площади проекции клубня предложена формула для вычисления объема урожая клубней с одного куста. Вычисленные значения объема урожая имеют высокую корреляцию со значениями массы урожая с одного куста. Показатель объема урожая предлагается использовать для общей характеристики клубнеобразования дикого картофеля по четырехбалльной шкале (от 0 до 3). В исследуемой группе образцов выявлены генотипы, обладающие нулевым, слабым, средним и высоким клубнеобразованием. Полученные данные частично соответствуют оценке клубнеобразования, проведенной по критериям ВИР. Различие в результатах оценки, вероятно, связано с условиями выращивания материала. Результаты применения метода позволяют рассматривать его как перспективный способ стандартного фенотипирования образцов коллекций диких видов картофеля.

Ключевые слова: Solanum; Petota; цифровое фенотипирование растений; дикие виды картофеля; SeedCounter; клубнеобразование.
\end{abstract}

\section{Introduction}

The use of wild potato species as a source of resistance to adverse environmental factors forms the background of the current potato breeding (Kiru, Rogozina, 2017). The need in phenotyping of large populations is a key point in studying the diversity of the cultivated potato and related species. The cultivated potato during its domestication and the breeding focused on the customer's needs has acquired considerable differences from its wild relatives in both its phenotype and genotype (Aversano et al., 2015). One of the major distinctions is the level of tuber formation. This trait is associated with the most important characteristic of the cultivated potato cultivars, namely, a high yield. A high-throughput morphometry of the cultivated potato tubers is a rather well-developed research area that has certain tools based on several approaches, including processing of digital tuber images (Rady, Guyer, 2015). The tuberization of cultivated potato is assessed with the help of the images captured with color, multispectral, and hyperspectral cameras. For analysis of these images, the corresponding methods have been elaborated that determine the main characteristics of the tuber, such as, the length to width ratio; predict the tuber length, width, and weight, as well as the defects inside and outside the specimen; and construct a tuber 3D model (Si et al., 2017, 2018; Su et al., 2017). There is also a mobile application, PotatoSize (https://www.hutton.ac.uk/ research/groups/information-and-computational-sciences/ potatosize), for measuring the proportions of cultivated potato tubers.

Unlike the cultivated Solanum tuberosum with its high adaptive ability to growth conditions, the majority of wild potato species form tubers only in the case of a short photoperiod and have considerable differences in the optimal environmental characteristics for a high yield. When studying the specimens of potato and closely related species from the collection of the Institute of Plant Industry (VIR), the morphological traits of their tubers are estimated, including its shape, tuber skin surface, depth of the eyes and stolon trail, and coloration of the skin (main and secondary) and flesh (Kiru et al., 2010). The morphological characters of tubers of the cultivated potato species are rather diverse (Huaman et al., 1977) versus the wild species of the section Petota, the tubers of which are less odd and diverse in their shape, color and eye depth and are sometimes missing in the botanical descriptions; however, some monographs give tuber images (Correll, 1962; Ochoa, 2004). The morphology of wild potato tubers has never been analyzed in terms of taxonomy (Spooner et al., 2004).

Any well-established criteria for tuberization and specific tuber features for the wild potato species are absent. As a rule, the wild potato plants are maintained in collections by growing in a climatic chamber or a greenhouse with differently set parameters. The phenotypic data obtained in such artificial environment are hard for processing and characterization since the phenotype of a plant grown in a climatic chamber may considerably differ from that "in field".

Here, we describe the experiment on growing wild potato species under local vegetation conditions (Novosibirsk region, Russia) during the season typical for growing the cultivated potato. In order to accelerate and standardize the estimation of tuber formation and phenotype of the wild potato species, the produced yield was phenotyped by digital imaging and image processing with the help of the SeedCounter mobile application (Komyshev et al., 2017) adapted to analyzing the wild potato tubers.

\section{Materials and methods}

In total, 12 genotypes of accessions belonging to nine wild potato species from the section Petota Dumort., genus Solanum L. according to the classification by Bukasov (1980) from the collection of the VIR Plant Genetic Resources Gene Bank, were used in the work (Table 1). 
Table 1. Genotypes of wild potato species from the collection of the Institute of Plant Industry*

\begin{tabular}{|c|c|c|c|c|}
\hline No. & Species & VIR catalog no. & Genotype & Tuberization (VIR data) \\
\hline 1 & S. dolichostigma Buk. (syn. S. chacoense Bitter) & 7613 & $6-2-n-2002$ & \multirow[t]{5}{*}{ Good } \\
\hline 2 & S. chacoense Bitter & 19759 & $3-42-2$ & \\
\hline 3 & S. chacoense Bitter & 22687 & $16-2016$ & \\
\hline 4 & S. commersonii Dunal & 21355 & $19-2016$ & \\
\hline 5 & S. fendleri A. Gray & 18242 & $549-3-2016$ & \\
\hline 6 & S. ehrenbergii Bitter (Rydb.) & 24207 & $715-2011$ & Medium \\
\hline 7 & S. jamesii Torr. & 24923 & $649-2011$ & \multirow[t]{2}{*}{ Good } \\
\hline 8 & S. pinnatisectum Dunal & 23569 & $18-7$ & \\
\hline 9 & S. pinnatisectum Dunal & 24239 & D-36-2011 & Poor \\
\hline 10 & S. polyadenium Greenm. & 24957 & $618-2011$ & Moderate \\
\hline 11 & S. verrucosum Schltdl. & 23015 & $346-2011$ & \multirow[t]{2}{*}{ Poor } \\
\hline 12 & S. tarijense Hawkes & 12637 & $14-1-2007$ & \\
\hline
\end{tabular}

* Data of the World Collection of the Institute of Plant Industry (VIR), issue 816 (2014).

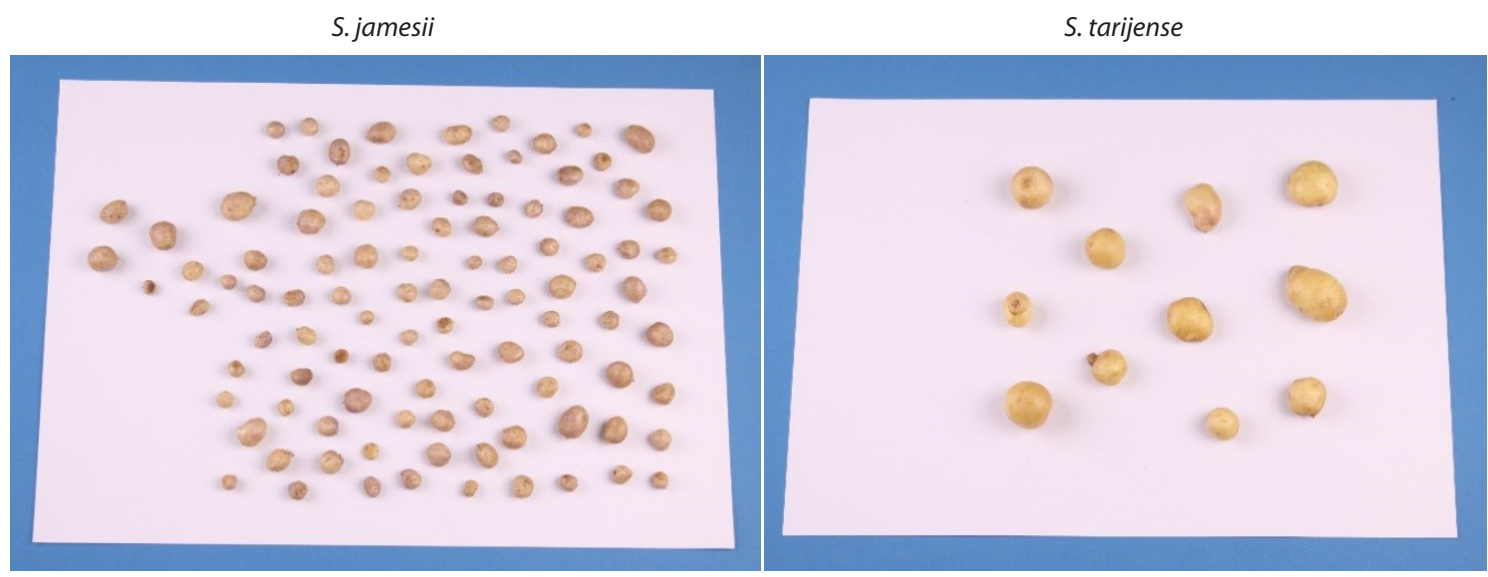

Fig. 1. Digital images of the tubers of two wild potato genotypes.

Cultivation conditions. The plants were grown in a hotbed covered with fleece, transparent for light, moisture, and air but impermeable for insects and pollen of other plants in the fields of the Siberian Research Institute of Plant Production and Breeding (Novosibirsk region, Russia). In the experiment, in vitro grown plantlets were planted in triplicate in 15 -L buckets filled with a Terra Vita universal nutrient soil (closed company ZAO MNPP FART, St. Petersburg, Russia) mixed in equal proportions with the natural soil taken from under the turf in a birch stand and grown to the end of vegetation with regular watering. The seedlings were planted on June 20, 2018 and tubers were harvested on completion of vegetation and death of the aboveground plant part (September 20, 2018). The tubers of nine different genotypes were harvested and three accessions $-S$. polyadenium, $S$. commersonii, and S. chacoense (22687) - failed to tuberize.

Image capturing and processing. The tubers harvested from one plant were loosely placed on an A3 sheet of white paper under artificial illumination (Fig. 1). The images were captured with a Canon EOS 50D camera (resolution, $4752 \times 3168$ ) according to the imaging protocol for the SeedCounter application (Komyshev et al., 2017).

Analysis of images by SeedCounter. The tuber images were analyzed by a desktop variant of the SeedCounter application (Komyshev et al., 2017; http://wheatdb.org/ seedcounter), modified for recognition of potato tubers instead of wheat grains. In addition to the length, width, and projected area, the following indices of tuber contour shape were also computed (Cervantes et al., 2016):

- Length to width ratio, $L / W$, which reflects one of the main tuber shape characteristics (Si et al., 2017).

- Circularity, $C$, reflecting the degree to which the contour is close to a circle. The values of this index vary from 0 to 1 ; the latter corresponds to an ideal circle,

$$
C=\frac{4 \pi \times \text { area }}{\text { perimeter }^{2}} \text {. }
$$


- Roundness, $R$, which is useful for the contours with numerous small bulbs on their surface. In this case, the perimeter increases and the circularity index takes on lower values, while the roundness index is independent of the irregularities of the perimeter,

$$
R=\frac{4 \times \text { area }}{\pi[\text { Major axis }]^{2}} .
$$

- Rugosity, $\mathrm{Rg}$, is determined as the ratio of contour perimeter to its convex hull perimeter,

$$
R g=\frac{P s}{P c},
$$

where $P s$ is the perimeter of the contour and $P c$, perimeter of the contour known as a convex hull, i. e., the least convex figure that contains all points of the image; and

- Solidity, $\mathrm{Sl}$, which is the ratio of contour area to its convex hull area,

$$
S l=\frac{\text { Contour Area }}{\text { Convex Hull Area }}
$$

The following assumptions were made to assess the volume of tuber yield from each plant: (1) tubers are ellipsoid with the equal height and width and the length is $k$-fold larger than the width $(k=L / W$ is the measured length to width ratio) and (2) the ellipsoid principle section area along the long axis is equal to the tuber projected area, $S$. Based on these assumptions, the following equation was obtained for assessing the tuber volume harvested from an individual plant (the total yield volume is equal to the volumes of all harvested tubers):

$$
\begin{gathered}
V=\sum_{i=1}^{n} V_{i}, \\
V_{i}=\frac{4}{3} \pi k_{i}\left(\frac{S_{i}}{\pi k_{i}}\right)^{\frac{3}{2}},
\end{gathered}
$$

where $n$ is the number of tubers; $V_{i}$ is the volume of one tuber; $S_{i}$ is the projected area of one tuber; and $k_{i}$ is the length to width ratio.

The equation was proposed based on the following reasoning. The volume of ellipsoid is

$$
V=\frac{4}{3} \pi a b c .
$$

The projected area of ellipsoid is an ellipse, the area of which is computed as

$$
S=\pi a b .
$$

The volume of ellipsoid and its projected area are related (taking into account that $b=c$ ) as

$$
V=\frac{4}{3} S b \text {. }
$$

Expressing $b$ via $S$, we get

$$
\begin{gathered}
a=k b, \\
S=\pi k b^{2}, \\
b=\sqrt{\frac{S}{\pi k} .}
\end{gathered}
$$

Then,

$$
V=\frac{4}{3} S b=\frac{4}{3} S \sqrt{\frac{S}{\pi k}}=\frac{4}{3} \pi k\left(\frac{S}{\pi k}\right)^{\frac{3}{2}} .
$$

Since SeedCounter computes the tuber projected area from its contour, this more precisely takes into account the specific shape features of an individual tuber. Correspondingly, the approximate estimate of the tuber volume was expressed via the projected area of the contour.

The total yield volume was also calculated from the estimate of potato tuber volume utilizing the nonlinear regression equation for the ratio of the projected area of tubers to their volume for a mixture of potato varieties proposed by Tabatabaeefar (2002):

$$
\begin{aligned}
& A=1.1 V^{0.71,} \\
& V=\left(\frac{A}{1.1}\right)^{1.408},
\end{aligned}
$$

where $A$ corresponds to the tuber projected area.

The data were statistically processed in the R environment (http://www.r-project.org). For each parameter, one-way ANOVA was used to analyze the effect of genotype on its value (https://www.rdocumentation.org/packages/stats/ versions/3.5.2/topics/aov). The particular pairs of specimens that displayed statistically significant differences were determined by multiple pairwise comparison according to the mean value of each parameter using Tukey's HSD test (https://www. rdocumentation.org/packages/stats/versions/3.5.2/topics/ TukeyHSD). The correlation between the tuber yield from one plant and the calculated values of yield volume was assessed using Pearson's product-moment correlation and the cor.test function in R environment (http://www.r-project.org).

\section{Results}

\section{General yield characterization of tested specimens}

The harvested yield was characterized according to the mean number and mean weight of the tubers from one plant (Table 2). Three genotypes failed to tuberize in all three replicates and one genotype (S. chacoense 3-42-2 no. 19759) formed tubers only in two replicates.

\section{Estimation of tuber morphology}

The indices that characterize tuber size and shape were computed by SeedCounter (Table 3). One-way ANOVA has shown a statistically significant effect of genotype on each parameter calculated by SeedCounter (Table 4).

Three genotypes - S. jamesii 649-2011, S. tarijense 14-1-2007, and $S$. chacoense 3-42-2 - are shown in Table 3 as examples to demonstrate statistically significant differences of one genotype from the remaining two ones. The S. jamesii genotype differs from the $S$. tarijense and $S$. chacoense genotypes in the tuber length, width, and projected area in a statistically significant manner (see Table 3 ); $S$. chacoense differs from $S$. jamesii and $S$. tarijense according to the length to width ratio in a statistically significant manner (see Table 3); and no statistically significant differences in circularity, rugosity, and solidity have been observed.

Thus, the tubers of the selected $S$. tarijense genotype can be initially characterized as large, smooth, and round; of the $S$. jamesii genotype, as small, smooth, and round; and of the $S$. chacoense genotype, as large, smooth, and elongated.

It has been shown using Tukey's test that 31 genotype pairs of the $36(86 \%)$ compared in a pairwise manner display sta- 
Table 2. Main yield characteristics of the studied genotypes of wild potato species (mean $\pm \mathrm{SE}$ )

\begin{tabular}{|c|c|c|c|c|c|}
\hline No. & Species & $\begin{array}{l}\text { VIR } \\
\text { catalog no. }\end{array}$ & Genotype & $\begin{array}{l}\text { Mean number } \\
\text { of tubers per plant }\end{array}$ & $\begin{array}{l}\text { Mean weight } \\
\text { of tubers per plant, } \mathrm{g}\end{array}$ \\
\hline 1 & S. dolichostigma & 7613 & $6-2-n-2002$ & $27.3 \pm 5.5$ & $143.3 \pm 43.6$ \\
\hline 2 & S. chacoense & 19759 & $3-42-2$ & $15.5 \pm 0.7$ & $109.0 \pm 66.5$ \\
\hline 3 & S. chacoense & 22687 & $16-2016$ & - & - \\
\hline 4 & S. commersonii & 21355 & $19-2016$ & - & - \\
\hline 5 & S. fendleri & 18242 & $549-3-2016$ & $13 \pm 5.3$ & $73.7 \pm 3.7$ \\
\hline 6 & S. ehrenbergii & 24207 & $715-2011$ & $32.7 \pm 7$ & $64.3 \pm 1.5$ \\
\hline 7 & S. jamesii & 24923 & $649-2011$ & $85.7 \pm 13.2$ & $100.0 \pm 15.0$ \\
\hline 8 & S. pinnatisectum & 23569 & $18-7$ & $33.3 \pm 7$ & $96.3 \pm 29.5$ \\
\hline 9 & S. pinnatisectum & 24239 & D-36-2011 & $8.7 \pm 4.5$ & $35.0 \pm 25.2$ \\
\hline 10 & S. polyadenium & 24957 & $618-2011$ & - & - \\
\hline 11 & S. verrucosum & 23015 & $346-2011$ & $5.3 \pm 3.2$ & $9.2 \pm 11.6$ \\
\hline 12 & S. tarijense & 12637 & $14-1-2007$ & $8.3 \pm 2.5$ & $95.7 \pm 40.9$ \\
\hline
\end{tabular}

* Two replicates.

Table 3. Values of the tuber size and shape parameters (mean \pm SE)

\begin{tabular}{|c|c|c|c|c|c|c|c|c|c|c|}
\hline No. & Species & Genotype & $\begin{array}{l}\text { Length, } \\
\mathrm{mm}\end{array}$ & $\begin{array}{l}\text { Width, } \\
\mathrm{mm}\end{array}$ & $\begin{array}{l}\text { Tuber } \\
\text { projected area, } \\
\mathrm{mm}^{2}\end{array}$ & $\begin{array}{l}\text { Length/ } \\
\text { width }\end{array}$ & $\begin{array}{l}\text { rcu- } \\
\text { rity }\end{array}$ & Roundness & Rugosity & Solidity \\
\hline 1 & S. dol & $6-2-r$ & \pm 5.55 & & & $1.19 \pm 0.13$ & \pm 0.07 & & 05 & \\
\hline 2 & S. chacoense & $3-42-2$ & $29.45 \pm 8.47$ & $22.48 \pm 6.07$ & $545.79 \pm 266.40$ & $1.31 \pm 0.16^{*}$ & $0.72 \pm 0.10$ & 0.76 & $1.16 \pm 0.11$ & $0.98 \pm 0.01$ \\
\hline 5 & S. fendleri & $549-3$ & $22.69 \pm 7.21$ & $19.21 \pm 5.76$ & $366.09 \pm 207.36$ & $1.19 \pm$ & $0.75 \pm$ & 0.84 & 1.14 & 0.98 \\
\hline 6 & S. ehrenbergii & 715 & $17.49 \pm 4.68$ & $14.70 \pm$ & $211.06 \pm$ & 1.19 & 0.77 & 0.84 & .07 & 0.98 \\
\hline 7 & S. jamesii & $649-2$ & $13.32 \pm 2.82^{*}$ & $11.41 \pm 2.19^{*}$ & $122.82 \pm 47.83^{*}$ & $1.17 \pm 0.12$ & $0.82 \pm 0.05$ & $0.86 \pm$ & 1.11 & $0.98 \pm 0.0$ \\
\hline 8 & S. pinnatisectum & $18-7$ & $18.76 \pm 4.95$ & $14.17 \pm 2.75$ & $211.72 \pm 88.38$ & $1.32 \pm 0.23$ & $0.68 \pm 0.12$ & $0.76 \pm 0.13$ & $1.19 \pm 0.12$ & $0.97 \pm 0.02$ \\
\hline 9 & S. pinnatisectum & D-36-2011 & $19.88=$ & $17.51 \pm 3.19$ & $279.58 \pm 9$ & 1.14 & $0.77 \pm 0.05$ & $0.88 \pm 0.06$ & 1.14 & 0.98 \\
\hline 11 & S. verrucosum & $346-2011$ & $14.46 \pm 5.05$ & $12.51 \pm 4.33$ & $156.05 \pm 109$ & $1.16 \pm 0.09$ & $0.79 \pm 0.05$ & $0.86 \pm 0.06$ & $1.14 \pm 0.05$ & $0.98 \pm 0.01$ \\
\hline 12 & S. tarijense & $14-1-2007$ & $3.63 \pm 6.65$ & $25.19 \pm 5.42$ & $587.38 \pm 253.86$ & $1.14 \pm 0.10$ & $0.78 \pm 0.07$ & $0.88 \pm 0.07$ & $1.14 \pm 0.05$ & $0.99 \pm 0$ \\
\hline
\end{tabular}

Note: The genotypes mentioned in the text are in grey. ${ }^{*}$ Statistically significant differences relative to the two other marked accessions (Tukey's test).

Table 4. Results of one-way ANOVA of the effect of genotype on the values of measured parameters

\begin{tabular}{|c|c|c|c|c|c|c|c|c|}
\hline $\begin{array}{l}\text { Significance } \\
\text { test }\end{array}$ & Area, $\mathrm{mm}^{2}$ & $\begin{array}{l}\text { Length, } \\
\mathrm{mm}\end{array}$ & $\begin{array}{l}\text { Width, } \\
\mathrm{mm}\end{array}$ & $\begin{array}{l}\text { Length/ } \\
\text { width }\end{array}$ & $\begin{array}{l}\text { Circu- } \\
\text { larity }\end{array}$ & Roundness & Rugosity & Solidity \\
\hline F value & 91.35 & 83.33 & 97.44 & 12.82 & 31.08 & 13.31 & 11.04 & 18.69 \\
\hline $\operatorname{Pr}(>\mathrm{F})$ & $<2 \mathrm{e}-16$ & $<2 \mathrm{e}-16$ & $<2 \mathrm{e}-16$ & $<2 \mathrm{e}-16$ & $<2 \mathrm{e}-16$ & $<2 \mathrm{e}-16$ & $1.05 e-14$ & $<2 \mathrm{e}-16$ \\
\hline
\end{tabular}

tistically significant differences in all measured parameters. Three-thirds of the pairs of genotypes $(75 \%)$ are reliably differentiable by analyzing tuber size characteristics (tuber projected area, length, and width) and $40 \%$ of the pairs are distinguishable by only size characteristic being the same in the remaining parameters. Not taking into account the tuber size characteristics, the shape indices on the average allow for statistically significant differentiation of approximately $30 \%$ of the pairs of genotypes of the studied species and three pairs $(8 \%)$ differ only in the shape characteristics and are the same in the size parameters. As has been shown, S. pinnatisectum genotype 18-7 no. 23569 differs from $S$. jamesii genotype 649- 
Table 5. Number of the pairs of genotypes distinguishable in a statistically significant manner with the SeedCounter application according to the considered parameters

\begin{tabular}{lll} 
Parameter & $\begin{array}{l}\text { Number } \\
\text { of significantly } \\
\text { distinguishable } \\
\text { pairs }\end{array}$ & $\begin{array}{l}\text { Ratio of the average number } \\
\text { of distinguishable pairs } \\
\text { of species to the number } \\
\text { of pairs }\end{array}$ \\
\hline Width & 28 & 0.78 \\
\hline Area & 27 & 0.75 \\
\hline Length/width & 14 & 0.72 \\
\hline Roundness & 14 & 0.39 \\
\hline Sircularity & 13 & 0.39 \\
\hline Solidity & 8 & 0.36 \\
\hline Rugosity & 7 & 0.22 \\
\hline
\end{tabular}

2011 no. 24923 and S. dolichostigma genotype 6-2-n-2002 no. 7613 in all eight considered parameters. Table 5 lists the data on the absolute and relative numbers of genotype pairs distinguishable in a statistically significant manner using each parameter alone.

\section{General assessment of tuber formation}

The obtained data were used to suggest the characteristic for assessment of tuberization by the tuber-forming wild potato species. The volume of the tubers harvested from one plant was selected as the main criterion since this characteristic is computable by analyzing images. According to the literature (Tabatabaeefar, 2002; Su et al., 2017), the volume of potato tubers is tightly correlated with the tuber weight, which is, as a rule, used for assessing the yield. The yield volume was estimated by approximating the tuber shape with ellipsoid, using the data on the projected area and the length to width ratio of each tuber, and with the help of the earlier proposed equation for cultivated potato (Tabatabaeefar, 2002).

The correlation with the measured tuber yield weight was chosen as the criterion for verification of the proposed method for estimating the tuber yield volume per plant. The total yield volume was assessed using two equations for each of the analyzed 26 plants to further calculate the Pearson correlation coefficient for the calculated and measured yield weights. The correlation coefficient for the values computed using the equation for the volume of ellipsoid expressed via the projected area of the contour was $0.87(p=7.839 \mathrm{e}-09$; $95 \%$ confidence interval: $0.7278559-0.9404020)$. As for the values computed according to the ratio of the volume to projected area using nonlinear regression, the correlation coefficient was $0.88(p=2.359 \mathrm{e}-09 ; 95 \%$ confidence interval: $0.7533180-0.9465927)$. These statistical results show a high degree of correlation and suggest that the proposed equations are applicable for assessing the yield volume of wild potato species.

Figure 2 shows the characteristics of mean tuber yield weight and volume for each of the examined genotypes. The accessions fall into three arbitrary groups with poor, medium, and good tuberization according to both tuber yield weight and volume. $a$

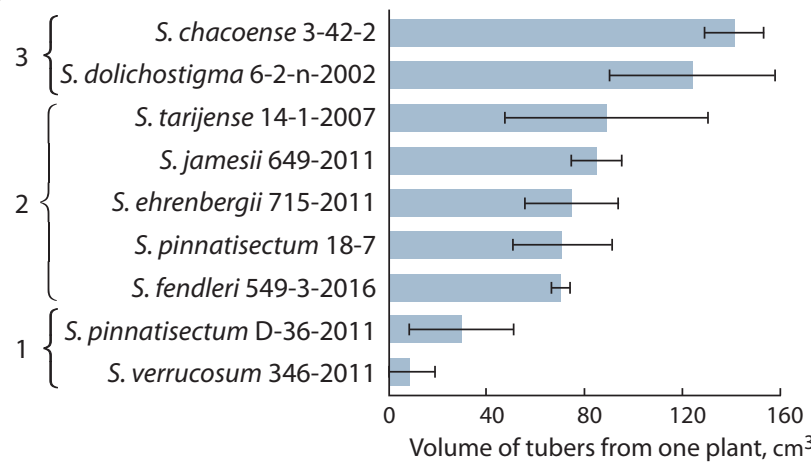

$b$

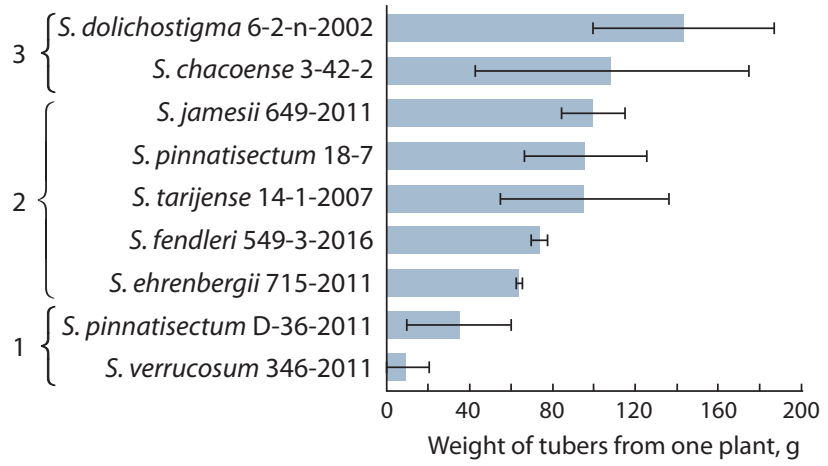

Fig. 2. Estimation of tuberization according to the $(a)$ volume and (b) weight of the tubers from one plant: genotypes with (1) poor, (2) medium, and (3) good tuberization.

The S. pinnatisectum D-36-2011 no. 24239 and $S$. verrucosum 346-2011 no. 23015 genotypes form the group with poor tuberization and the $S$. dolichostigma (synonym for S. chacoense) 6-2-n-2002 no. 7613 and S. chacoense 3-42-2 no. 19759 genotypes, members of the same species, the group with good tuberization. The remaining genotypes form an intermediate (medium) group.

The values of the degree of tuberization (1 to 3 ) or its absence (0) were ascribed to the groups. The results were compared with each other and the data from the World Collection of the Institute of Plant Industry (Catalog..., 2014) (Table 6). Our estimates for tuberization coincided with that of the Institute of Plant Industry for genotypes nos. 1, 2, 6, 9, and 11 (see Table 6).

\section{Discussion}

Here, we describe a new approach to harvesting and analyzing the information about morphological characteristics of wild potato tubers as well as propose a new criterion for assessing the tuberization of wild potato species.

The methods utilizing digital images of tubers and their analysis are intended for estimation of the yield of cultivated potato cultivars and provide the information about its quality and usefulness. Any specialized methods allowing for assessment of tuberization by wild potato species are unavailable in the relevant literature and the existing botanical descriptions of tubers are sparse and inapplicable to adequately compare similar characteristics for different accessions. However, 
Table 6. Grouping of the examined genotypes using the proposed criteria according to tuber yield characteristics

\begin{tabular}{|c|c|c|c|c|c|}
\hline \multirow[t]{3}{*}{ No. } & \multirow[t]{3}{*}{ Species } & \multirow[t]{3}{*}{ Genotype } & \multicolumn{3}{|l|}{ Tuberization } \\
\hline & & & \multicolumn{2}{|c|}{ from one plant according to our estimates using } & \multirow[t]{2}{*}{ VIR data } \\
\hline & & & mean volume & mean weight & \\
\hline 1 & S. dolichostigma* & $6-2-n-2002$ & 3 & 3 & \multirow[t]{5}{*}{ Good } \\
\hline 2 & S. chacoense & $3-42-2$ & 3 & 3 & \\
\hline 3 & S. chacoense & $16-2016$ & 0 & 0 & \\
\hline 4 & S. commersonii & $19-2016$ & 0 & 0 & \\
\hline 5 & S. fendleri & $549-3-2016$ & 2 & 2 & \\
\hline 6 & S. ehrenbergii* & $715-2011$ & 2 & 2 & Medium \\
\hline 7 & S. jamesii & $649-2011$ & 2 & 2 & \multirow[t]{2}{*}{ Good } \\
\hline 8 & S. pinnatisectum & $18-7$ & 2 & 2 & \\
\hline 9 & S. pinnatisectum* & D-36-2011 & 1 & 1 & Poor \\
\hline 10 & S. polyadenium & $618-2011$ & 0 & 0 & Moderate \\
\hline 11 & S. verrucosum ${ }^{*}$ & $346-2011$ & 1 & 1 & \multirow[t]{2}{*}{ Poor } \\
\hline 12 & S. tarijense & $14-1-2007$ & 2 & 2 & \\
\hline
\end{tabular}

* Matching of the estimates of tuberization according to the mean tuber yield volume, mean tuber yield weight, and the data of the Institute of Plant Industry (VIR).

tuberization and tuber characteristics are basic economic features of the potato. The information about tuberization of potato accessions is of a high value when selecting the donor specimens in breeding.

Incomparable cultivation conditions and a wide reaction norm of the wild species contribute to the difficulties in estimation of tuberization. We have conducted an experiment on cultivation of wild potato species under conditions of our region, which in several parameters are close to field conditions (soil composition, light day, and temperature), which has made it possible to take into account the degree of adaptation of the examined accessions to regional climate.

Processing of the digital images of wild potato tubers with the help of the elaborated SeedCounter application allows for quantification of their phenotypic characteristics related to tuber number, size, and shape. The tuber size parameters (length, width, and projected area) give the most statistically significant differences between species, while the remaining morphological parameters are less specific; however, various combinations of these parameters detect statistically significant differences between individual accessions with a high accuracy. The proposed method distinguishes not only between individual species, but also between different accessions of the same species based on the characteristics of tuber morphology. This feature of the proposed method can be useful when selecting the optimal accession of a particular species for different breeding challenges.

The phenotyping of wild potato by the proposed method forms a high-capacity background for interpretation of the obtained data. Digital phenotyping makes it possible to elaborate new characteristics of the described phenotypes and genotypes; in particular, these characteristics may be used for estimation of tuberization. The new criterion for assessing tuber formation - the volume of tubers harvested from one plant - is proposed based on the measurement of the projected area of each tuber and the length to width ratio.
A visual assessment of the tuber shape and the fact that the shape parameters inconsiderably (as a rule, by $10 \%$; see Table 2) vary within the studied species suggest that the tuber shape may be approximated by an ellipsoid. As has been shown earlier, the volume and weight of the cultivated potato tubers display a stably high correlation; correspondingly, the estimation of tuber volume can be used as a tool for predicting the weight of the yield (Tabatabaeefar, 2002; Su et al., 2017). A comparison of the calculated estimate of the tuber yield from one plant and the measured weight of this yield demonstrates a strong correlation of these parameters. Thus, our results comply with the literature data and suggest that the proposed criterion allows for an adequate estimation of tuberization within one experiment.

However, in the further use of this method for characterization of a wide range of genotypes, it is necessary to take into account the probability of interspecific differences in the tuber specific weight. Correspondingly, it is recommended when applying this method to a new set of accessions to construct a regression model of the dependence of tuber volume on their weight. The calculated data match the data by the Institute of Plant Industry in five cases of the overall 12. Presumably, the difference in results on tuberization is explainable by different growth conditions. The method proposed for assessing tuberization is easily adaptable to different growth conditions. This estimation in several independent experiments will make it possible to determine the degree of tuberization using a four-point scale ( $0-3)$ for each accession.

\section{Conclusion}

Estimation of quantitative characteristics of tuberization by analyzing tuber images with the help of the SeedCounter application is a promising method for phenotyping of the species belonging to the section Petota Dumort., genus Solanum L. A regular use of the SeedCounter-based phenotyping when describing collections of wild potato species will 
allow a large volume of new phenotypic data to be harvested and systematized as well as new characteristics advantageous for using particular accessions in breeding to be detected.

\section{References}

Aversano R., Contaldi F., Ercolano M.R., Grosso V., Iorizzo M., Tatino F., Delledonne M., Xumerle L., Molin A.D., Avanzato C., Ferrarini A., Sanseverino W., Cigliano R.A., Capella-Gutierrez S., Gabaldón T., Frusciante L., Bradeen J.M., Carputo D. The Solanum commersonii genome sequence provides insights into adaptation to stress conditions and genome evolution of wild potato relatives. Plant Cell. 2015;27(4):954-968. DOI 10.1105/tpc.114.135954.

Bukasov S.M. Taxonomy of potato species of the section Tuberarium (Dun.) Buk: a review. Byulleten VIR = Bulletin of the Institute of Plant Industry (Leningrad). 1980;105:6. (in Russian)

Catalog of the VIR Global Collection. Issue 816. Clone Collection of Wild Potato Species. St. Petersburg, 2014. (in Russian)

Cervantes E., Martín J.J., Saadaoui E. Updated methods for seed shape analysis. Scientifica. 2016;2016:5691825. DOI 10.1155/2016/ 5691825.

Correll D.S. The Potato and its Wild Relatives. Renner: Texas Res. Found., 1962.

Huaman Z., Williams J., Salhuna W., Vincent L. Descriptors for the Cultivated Potato. Rome, Italy: Int. Board for Plant Genet. Res., 1977;77(32):47.

Kiru S.D., Kostina L.I., Truskinov E.V., Zoteeva N.M., Rogozina E.V., Koroleva L.V., Fomina V.E., Palekha S.V., Kosareva O.S., Kirillov D.A. Guidelines for the Maintenance and Study of the World
Collection of Potatoes. St. Petersburg: VIR Publ., 2010. (in Russian)

Kiru S.D., Rogozina E.V. Mobilization, conservation and study of cultivated and wild potato genetic resources. Vavilovskii Zhurnal Genetiki i Selektsii = Vavilov Journal of Genetics and Breeding. 2017;21(1):7-15. DOI 10.18699/VJ17.219. (in Russian)

Komyshev E., Genaev M., Afonnikov D. Evaluation of the SeedCounter, a mobile application for grain phenotyping. Front. Plant Sci. 2017;7:1990. DOI 10.3389/fpls.2016.01990.

Ochoa C.M. The Potatoes of South America: Peru. Int. Potato Center, 2004.

Rady A.M., Guyer D.E. Rapid and/or nondestructive quality evaluation methods for potatoes: a review. Comput. Electron. Agr. 2015;117: 31-48. DOI 10.1016/j.compag.2015.07.002.

Si Y., Sankaran S., Knowles N.R., Pavek M.J. Potato tuber length-width ratio assessment using image analysis. Am. J. Potato Res. 2017; 94(1):88-93. DOI 10.1007/s12230-016-9545-1.

Si Y., Sankaran S., Knowles N.R., Pavek M.J. Image-based automated potato tuber shape evaluation. J. Food Meas. Charact. 2018; 12(2):702-709. DOI 10.1007/s11694-017-9683-2.

Spooner D.M., Van den Berg R.G., Rodrigues A., Bamberg J., Hijmans R.J., Lara-Cabrera S.I. Wild Potatoes (Solanum section Peto$t a$; Solanaceae) of North and Central America. Syst. Bot. Monogr. 2004;68.

Su Q., Kondo N., Li M., Sun H., Al Riza D.F. Potato feature prediction based on machine vision and 3D model rebuilding. Comput. Electron. Agr. 2017;137:41-51. DOI 10.1016/j.compag.2017.03.020.

Tabatabaeefar A. Size and shape of potato tubers. Int. Agrophys. 2002; 16(4):301-306.

ORCID ID

K.A. Ivanova orcid.org/0000-0002-1868-635X

D.A. Afonnikov orcid.org/0000-0001-9738-1409

A.V. Kochetov orcid.org/0000-0003-3151-5181

E.V. Rogozina orcid.org/0000-0002-2743-068X

S.V. Gerasimova orcid.org/0000-0001-8626-1831

Acknowledgements. The work was supported by the Russian Foundation for Basic Research (grant no. 18-316-00068) and the plant material used in the work is covered by the project of the Institute of Plant Industry (no. 0662-2019-0004). The SeedCounter mobile application was adapted to analysis of tuber shape under project no. 17-74-10148 of the Russian Science Foundation. The data were analyzed using the facilities of the Bioinformatics joint access center (with support of the state project of the Institute of Cytology and Genetics, Siberian Branch, Russian Academy of Sciences). The work with plants was performed at the joint access center "Laboratory of Artificial Plant Growth" and experimental fields (under state project of the Institute of Cytology and Genetics, Siberian Branch, Russian Academy of Sciences).

Conflict of interest. The authors declare no conflict of interest.

Received February 1, 2019. Revised April 8, 2019. Accepted April 15, 2019. Published online April $29,2019$. 